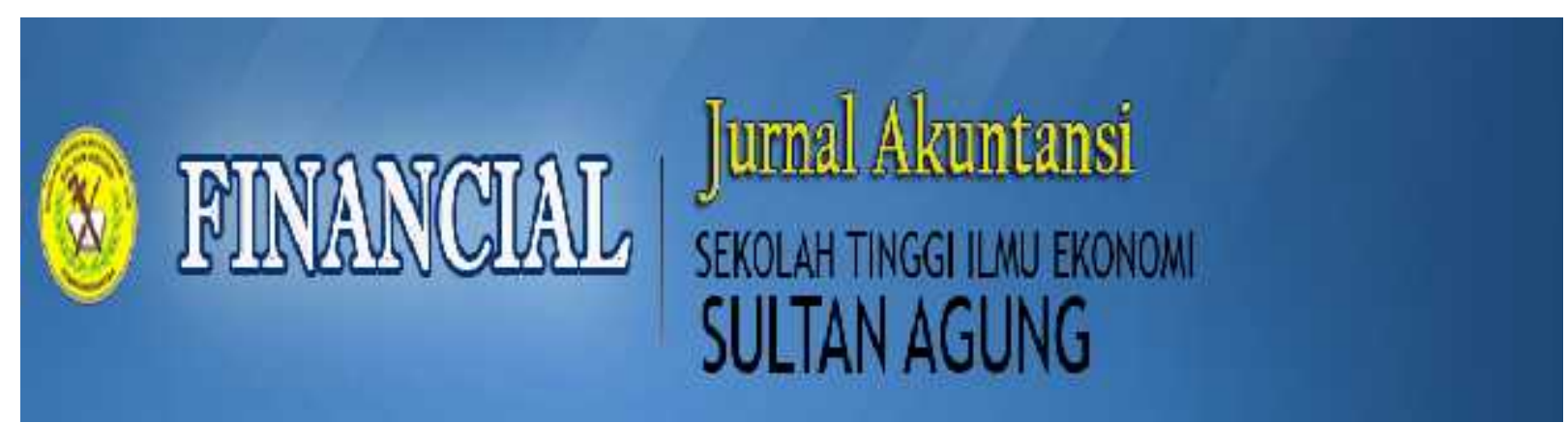

\title{
PENGARUH LEVERAGE DAN PROFITABILITAS TERHADAP NILAI PERUSAHAAN \\ DENGAN KEBIJAKAN DIVIDEN SEBAGAI VARIABEL MODERATING PADA PERUSAHAAN SUB SEKTOR PROPERTY DAN REAL ESTATE YANG TERDAFTAR DI BURSA EFEK INDONESIA
}

\author{
Oleh : \\ Tio Friska Simanjuntak \\ S1 Akuntansi \\ Yansen Siahaan, Ady Inrawan, Supitriyani
}

Abstrak

Tujuan dari penelitian ini adalah untuk mengetahui: 1. Gambaran leverage, profitabilitas, kebijakan dividen dan nilai perusahaan. 2. Pengaruh leverage dan profitabilitas terhadap nilai perusahaan baik secara simultan maupun parsial. 3. Kemampuan kebijakan dividen dalam memoderasi hubungan leverage dan profitabilitas dengan nilai perusahaan pada Perusahaan Sub Sektor Property dan Real Estate yang Terdaftar di Bursa Efek Indonesia secara parsial. Penelitian ini dilakukan dengan metode analisis deskriptif kualitatif dan analisis deskriptif kuantitatif. Pengumpulan data dilakukan dengan metode dokumentasi. Teknik analisis yang digunakan adalah uji asumsi klasik, analisis regresi linear berganda, koefisien korelasi dan determinasi serta uji hipotesis.

Hasil penelitian ini dapat disimpulkan sebagai berikut: 1. Leverage, profitabilitas, kebijakan dividen dan nilai perusahaan mengalami penurunan. 2. Hasil pengujian regresi linear berganda tanpa moderating diketahui bahwa leverage dan profitabilitas berpengaruh positif terhadap nilai perusahaan. 3. Hasil pengujian regresi linear berganda dengan moderating diketahui bahwa kebijakan dividen memperlemah hubungan leverage dengan nilai perusahaan, sementara kebijakan dividen memperkuat hubungan profitabilitas dengan nilai perusahaan. 4. Hasil uji hipotesis pertama menunjukkan bahwa leverage dan profitabilitas berpengaruh signifikan terhadap nilai perusahaan baik secara simultan maupun parsial. 5. Hasil uji hipotesis kedua menunjukkan bahwa secara parsial kebijakan dividen mampu memoderasi namun tidak signifikan hubungan leverage dengan nilai perusahaan, sementara kebijakan dividen mampu memoderasi secara signifikan hubungan profitabilitas dengan nilai perusahaan.

Saran yang dapat diberikan adalah sebaiknya perusahaan mengelola aset secara efisien, meningkatkan profitabilitas perusahaan, dan meningkatkan pembagian dividen sehingga nilai perusahaan juga akan meningkat.

Kata Kunci : Leverage, Profitabilitas, Kebijakan Dividen dan Nilai Perusahaan.

\section{Abstract}

The aim of this research are to determine: 1. The description of leverage, profitability, dividend policy and firm value. 2. The effect of leverage and profitability on firm value either simultaneously or partially. 3. The ability of dividend policy to moderated leverage and profitability relationship with firm value at Sub Sector Property and Real Estate on The Indonesia Stock Exchange partially.

The result of the research can be summarized as follows: 1. Leverage, profitability, dividend policy and firm value has decreased. 2. The results of multiple linear regression test without moderating is known that leverage and profitability has a positive effect on firm value. 3 . The results of multiple linear regression test with moderating variable is known that dividend policy weakens the relationship of leverage with firm value, while dividend policy strengthens the relationship of profitability with firm value. 4. The results of the first hypothesis test can be concluded that leverage and profitability have significant effect on firm value either simultaneously and partially. 5 . The second hypothesis test results can be concluded that partially dividend policy can moderate but has no significant relationship of leverage with firm value while dividend policy can moderate has significant relationship of profitability with firm value.

This research suggest that company should manage assets efficiently, increase company profit, and increase dividend distribution so that firm value will also increase.

Keywords: Leverage, Profitability, Dividend Policy and Firm Value

\section{PENDAHULUAN}

\subsection{Latar Belakang Masalah}

Pada umumnya yang menjadi tujuan utama suatu perusahaan adalah meningkatkan kemakmuran pemilik perusahaan atau para pemegang saham melalui peningkatan nilai perusahaan. Nilai perusahaan digunakan untuk mengukur keberhasilan perusahaan karena dengan meningkatnya nilai perusahaan, maka kemakmuran pemilik perusahaan dan pemegang saham juga akan meningkat. 
Nilai perusahaan dipengaruhi oleh beberapa faktor seperti leverage. Leverage memberikan risiko bagi perusahaan berupa beban tetap kepada pemegang saham, jika perusahaan tidak mampu membayar beban tetap maka akan mempengaruhi nilai perusahaan. Faktor lainnya adalah profitabilitas merupakan kemampuan perusahaan dalam menghasilkan laba. Selain itu nilai perusahaan juga dipengaruhi oleh kebijakan dividen yang merupakan keputusan perusahaan untuk membagikan dividen kepada para pemegang saham dalam bentuk dividen atau ditahan sebagai laba ditahan untuk menambah modal, guna pembiayaan investasi perusahaan dimasa yang akan datang.

Perusahaan yang menjadi objek dalam penelitian ini adalah Perusahaan Sub Sektor Property dan Real Estate yang terdaftar di Bursa Efek Indonesia. Perusahaan ini bergerak pada bidang industri property dan real estate. Produk yang dihasilkan dari industri property dan real estate berupa perumahan, apartment, gedung perkantoran, serta pusat perbelanjaan berupa mall. Berikut ini disajikan gambaran leverage, profitabilitas, kebijakan dividen dan nilai perusahaan pada Perusahaan Sub Sektor Property dan Real Estate yang terdaftar di Bursa Efek Indonesia periode 2013-2016:

$$
\text { Tabel } 1.1
$$

Gambaran Leverage, Profitabilitas, Kebijakan Dividen dan Nilai Perusahaan pada Perusahaan

Sub Sektor Property dan Real Estate yang Terdaftar di Bursa Efek Indonesia Periode 2013-2016

\begin{tabular}{|c|c|c|c|c|}
\hline Tahun & $\begin{array}{c}\text { Leverage } \\
\text { (Kali) }\end{array}$ & $\begin{array}{c}\text { Profitab } \\
\text { ilitas } \\
\text { (Kali) }\end{array}$ & $\begin{array}{c}\text { Kebijakan } \\
\text { Dividen } \\
\text { (Kali) }\end{array}$ & $\begin{array}{c}\text { Nilai } \\
\text { Perusaha } \\
\text { an (Kali) }\end{array}$ \\
\hline 2013 & 0,45 & 0,09 & 0,46 & 2,21 \\
\hline 2014 & 0,44 & 0,09 & 0,20 & 2,77 \\
\hline 2015 & 0,44 & 0,07 & 0,19 & 2,27 \\
\hline 2016 & 0,43 & 0,08 & 0,21 & 2,30 \\
\hline $\begin{array}{c}\text { Rata- } \\
\text { Rata }\end{array}$ & $\mathbf{0 , 4 4}$ & $\mathbf{0 , 0 8}$ & $\mathbf{0 , 2 6}$ & $\mathbf{2 , 3 9}$ \\
\hline
\end{tabular}

Sumber: Laporan Keuangan Perusahaan Sub Sektor Property dan Real Estate (www.idx.co.id), data diolah.

Berdasarkan Tabel $1.1 \mathrm{di}$ atas, dapat dilihat bahwa nilai leverage (DAR) pada periode 2013-2016 mengalami fluktuasi dan cenderung menurun diikuti dengan penurunan nilai perusahaan (PBV). Hal ini tidak sejalan dengan pendapat Brigham dan Joel (2011:171), "tingkat utang yang tinggi juga akan meningkatkan risiko perusahaan, dan hal ini akan meningkatkan biaya ekuitas dan mengakibatkan terjadinya penurunan pada harga saham".

Profitabilitas (ROA) mengalami fluktuasi dan cenderung menurun diikuti dengan penurunan nilai perusahaan (PBV). Hal ini sejalan dengan pendapat Brigham dan Joel
(2010:150), "jika rasio likuiditas, manajemen aset, manajemen hutang dan profitabilitas semuanya terlihat baik dan apabila kondisi ini berjalan terus menerus secara stabil maka rasio nilai pasar juga akan tinggi, harga saham kemungkinan tinggi sesuai dengan yang diperkirakan". Namun tingkat penurunan profitabilitas tidak sebanding dengan penurunan nilai perusahaan. Hal ini terlihat pada tahun 2015, profitabilitas menurun sebesar 2\% dari tahun 2014 sedangkan nilai perusahaan menurun sebesar $50 \%$ dari tahun 2014.

Kebijakan dividen (DPR) mengalami fluktuasi dan cenderung menurun diikuti dengan penurunan nilai perusahaan (PBV). Namun pada tahun 2014, terlihat bahwa kebijakan dividen mengalami penurunan sedangkan nilai perusahaan mengalami peningkatan. Tingkat penurunan kebijakan dividen tidak sebanding dengan peningkatan nilai perusahaan, kebijakan dividen menurun sebesar $26 \%$ dari tahun 2013 sedangkan nilai perusahaan meningkat sebesar $56 \%$ dari tahun 2013. Dengan demikian dapat dinyatakan bahwa hal ini tidak sejalan dengan pendapat Myron Gordon dan John Lintner dalam Sudana (2011:169) berdasarkan teori birth in the hand, "kebijakan dividen berpengaruh positif terhadap harga pasar saham. Artinya bahwa jika dividen yang dibagikan perusahaan semakin besar, harga pasar saham perusahaan tersebut akan semakin tinggi dan sebaliknya".

\subsection{Rumusan Masalah}

1. Bagaimana gambaran leverage, profitabilitas, kebijakan dividen dan nilai perusahaan pada Perusahaan Sub Sektor Property dan Real Estate yang terdaftar di Bursa Efek Indonesia.

2. Bagaimana pengaruh leverage dan profitabilitas terhadap nilai perusahaan pada Perusahaan Sub Sektor Property dan Real Estate yang terdaftar di Bursa Efek Indonesia secara simultan maupun parsial.

3. Bagaimana kemampuan kebijakan dividen dalam memoderasi hubungan leverage dan profitabilitas dengan nilai perusahaan pada Perusahaan Sub Sektor Property dan Real Estate yang terdaftar di Bursa Efek Indonesia secara parsial.

\subsection{Tujuan Penelitian}

1. Untuk mengetahui gambaran leverage, profitabilitas, kebijakan dividen dan nilai perusahaan pada Perusahaan Sub Sektor Property dan Real Estate yang terdaftar di Bursa Efek Indonesia.

2. Untuk mengetahui pengaruh leverage dan profitabilitas terhadap nilai perusahaan pada Perusahaan Sub Sektor Property dan Real Estate yang terdaftar di Bursa Efek Indonesia secara simultan maupun parsial. 
3. Untuk mengetahui kemampuan kebijakan dividen dalam memoderasi hubungan leverage dan profitabilitas dengan nilai perusahaan pada Perusahaan Sub Sektor Property dan Real Estate yang terdaftar di Bursa Efek Indonesia secara parsial.

\subsection{Metodologi Penelitian}

Penelitian ini menggunakan data sekunder yang diakses dari situs www.idx.co.id. Desain penelitian yang digunakan adalah penelitian kepustakaan (library research). Populasi dalam penelitian ini berjumlah 46 perusahaan dan yang menjadi sampel penelitian sebanyak 15 perusahaan. Teknik pengumpulan data yang digunakan adalah metode dokumentasi. Teknik analisa data yang digunakan adalah uji asumsi klasik, analisis deskriptif kualitatif dan analisis deskriptif kuantitatif.

\section{LANDASAN TEORI}

\subsection{Akuntansi}

Pengertian akuntansi menurut Rudianto (2009:4), "sebuah sistem informasi yang menghasilkan informasi keuangan kepada pihak-pihak yang berkepentingan mengenai kegiatan ekonomi dan kondisi suatu perusahaan". Menurut Hery (2009:1), "tujuan akuntansi adalah memberikan informasi yang dapat digunakan dalam pengambilan keputusan ekonomi".

\subsection{Analisa Laporan Keuangan}

Menurut Horne dan John (2012:154), "analisis laporan keuangan adalah seni untuk mengubah data dari laporan keuangan ke informasi yang berguna bagi pengambil keputusan". Menurut Kasmir (2010:92), tujuan dari analisis laporan keuangan yaitu sebagai berikut:

1. Dapat mengetahui posisi keuangan perusahaan (dalam satu periode tertentu). Baik harta, kewajiban, modal, maupun hasil usaha, yang telah dicapai untuk beberapa periode.

2. Digunakan untuk mengetahui kelemahan apa saja yang menjadi kekurangan perusahaan.

3. Digunakan untuk mengetahui kekuatan yang dimiliki perusahaan.

4. Digunakan untuk mengetahui langkahlangkah perbaikan apa saja yang perlu dilakukan ke depan yang berkaitan dengan posisi keuangan perusahaan saat ini.

5. Digunakan untuk melakukan penilaian kinerja manajemen ke depan apakah perlu penyegaran atau tidak karena sudah dianggap berhasil atau gagal.

6. Dapat pula digunakan sebagai pembanding dengan perusahaan sejenis tentang hasil yang mereka capai.

Menurut Weygandt, Donald dan Paul (2008:389), terdapat tiga cara yang digunakan untuk mengevaluasi pentingnya data laporan keuangan. Tiga cara yang digunakan adalah sebagai berikut:

1. Analisis Horizontal (Horizontal Analysis)

2. Analisis Vertikal (Vertical Analysis)

3. Analisis Rasio (Ratio Analysis)

\subsection{Rasio Keuangan}

Menurut Weygandt, Donald dan Paul (2008:395), "rasio keuangan menyatakan sebuah hubungan di antara pos-pos tertentu dari data laporan keuangan. Sebuah rasio menyatakan hubungan matematika antar tiap kuantitas. Hubungan tersebut dinyatakan dalam bentuk persentase, tingkat dan proporsi sederhana".

Menurut Horne dan John (2012:167), ada lima jenis rasio penilaian terhadap laporan keuangan yaitu:

1. Rasio Likuiditas

2. Rasio Solvabilitas

3. Rasio Cakupan (Coverage Ratio)

4. Rasio Aktivitas

5. Rasio Profitabilitas

\subsection{Leverage}

Menurut Sudana (2011:20), "leverage adalah rasio yang mengukur berapa besar penggunaan utang dalam pembelanjaan perusahaan". Menurut Kasmir (2010:112), terdapat beberapa cara untuk mengukur leverage, yaitu sebagai berikut:

1. Debt to Assets Ratio (Debt Ratio)

2. Debt to Equity Ratio

3. Long Term Debt to Equity Ratio

4. Times Interest Earned

5. Fixed Charge Coverage

Menurut Brigham dan Joel (2011:155), ada empat faktor yang mempengaruhi leverage yaitu sebagai berikut:

1. Risiko usaha

2. Posisi Pajak Perusahaan

3. Fleksibilitas keuangan

4. Konservatisme atau Keagresifan Manajerial

\subsection{Profitabilitas}

Menurut Halim (2007:156), "profitabilitas adalah rasio untuk mengukur sampai seberapa besar efektivitas manajemen dalam mengelola aset dan ekuitas yang dimiliki perusahaan untuk menghasilkan laba". Menurut Sudana (2011:22), terhadap beberapa cara untuk mengukur besar kecilnya profitabilitas, yaitu sebagai berikut:

1. Return on Assets (ROA)

2. Return on Equity (ROE)

3. Profit Margin Ratio

4. Basic Earning Power

Menurut Riyanto (2009:37), faktor-faktor yang mempengaruhi nilai profitabilitas adalah sebagai berikut:

1. Penjualan

2. Efisiensi Modal Kerja

3. Profit Margin

4. Struktur Modal

\subsection{Kebijakan Dividen}


Menurut Sudana (2011:167), "kebijakan dividen adalah keputusan besarnya persentase laba bersih setelah pajak yang dibagikan sebagai dividen kepada pemegang saham". Sedangkan Syahyunan (2015:314), mengemukakan kebijakan dividen sebagai "keputusan apakah laba yang diperoleh perusahaan (pada akhir tahun), akan dibagi kepada pemegang saham (dividen), atau akan ditahan untuk menambah modal guna pembiayaan investasi di masa yang akan datang".

Menurut Brigham dan Joel (2010:69), "Dividend Payout Ratio (DPR), merupakan persentase dari laba bersih yang akan dibayarkan sebagai dividen tunai kepada pemegang saham". Menurut Astuti (2004:145), ada beberapa faktor yang dapat mempengaruhi kebijakan dividen, yaitu sebagai berikut:

1. Peraturan pemerintah

2. Hambatan dalam perjanjian-kontrak

3. Hambatan internal

4. Perkiraan pertumbuhan di masa yang akan datang

5. Pertimbangan pemilik perusahaan

6. Pertimbangan pasar

\subsection{Nilai Perusahaan}

Nilai perusahaan merupakan persepsi investor terhadap perusahaan yang dikaitkan dengan harga saham. Menurut Brigham dan Joel (2010:150), "nilai perusahaan adalah rasio yang menghubungkan harga saham perusahaan dengan laba, arus kas dan nilai buku per sahamnya".

Menurut Subramanyam dan John (2010:45), terdapat beberapa jenis rasio yang berkaitan dengan ukuran pasar (market measure) atau nilai perusahaan antara lain:

1. Rasio Harga Terhadap Laba (Price to Earning Ratio)

2. Hasil Laba (Earning Yield)

3. Hasil Dividen (Dividend Yield)

4. Tingkat Pembayaran Dividen (Dividend Payout Ratio)

5. Harga Terhadap Nilai Buku (Price to Book Value)

$\begin{array}{lcc}\text { 2.8. } \begin{array}{l}\text { Pengaruh } \\ \text { Profitabilitas } \\ \text { Perusahaan }\end{array} & \begin{array}{c}\text { Leverage } \\ \text { terhadap }\end{array} & \text { dan } \\ & & \end{array}$

Menurut Brigham dan Joel (2010:150), "jika rasio likuiditas, manajemen aset, manajemen hutang dan profitabilitas semuanya terlihat baik dan apabila kondisi ini berjalan terus menerus secara stabil maka rasio nilai pasar juga akan tinggi, harga saham kemungkinan tinggi sesuai dengan yang diperkirakan". Apabila tingkat leverage dan profitabilitas yang dihasilkan oleh perusahaan baik maka nilai pasarnya juga semakin tinggi dan harga saham juga akan semakin tinggi.

\subsection{Pengaruh Leverage dan Profitabilitas terhadap Nilai Perusahaan dengan Kebijakan Dividen sebagai Variabel Moderating}

Kebijakan dividen sebagai pemoderasi antara leverage dan profitabilitas dengan nilai perusahaan dikarenakan secara teori kebijakan dividen dapat dihubungkan dengan nilai perusahaan. Berdasarkan hasil penelitian Lestari (2017), "menyatakan bahwa kebijakan dividen memperkuat hubungan leverage dan profitabilitas terhadap nilai perusahaan".

$\mathrm{Hal}$ ini dikarenakan perusahaan membutuhkan dana tambahan untuk melakukan kegiatan operasional perusahaan, namun penggunaan utang dapat meningkatkan risiko keuangan perusahaan sehingga dapat menurunkan profitabilitas perusahaan. Perusahaan perlu mempertimbangkan risiko keuangan agar dapat memperoleh laba yang diharapkan, sehingga dengan laba yang diperoleh perusahaan mampu membayarkan dividen kepada para investor. Dengan demikian nilai perusahaan akan meningkat.

\section{PEMBAHASAN}

3.1. Analisis

3.1.1. Analisis Deskriptif Kualitatif

3.1.1.1. Leverage pada Perusahaan Sub Sektor Property dan Real Estate Periode 2013-2016

Berikut ini grafik rata-rata leverage Perusahaan Sub Sektor Property dan Real Estate yang diukur dengan Debt to Assets Ratio (DAR):

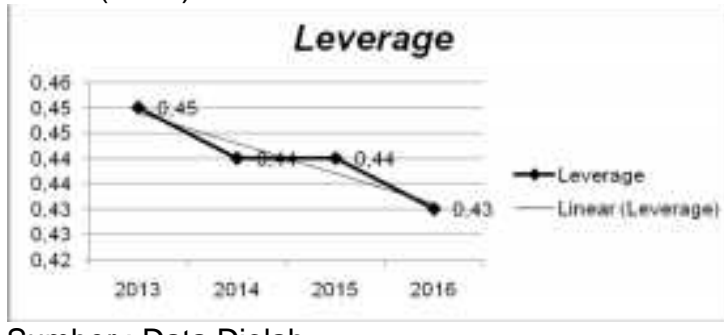

Sumber : Data Diolah

Gambar 3.1

Grafik Rata-rata Leverage pada Perusahaan Sub Sektor Property dan Real Estate Periode 2013-2016

Dari Gambar 3.1, dapat dilihat bahwa leverage yang diukur dengan Debt to Assets Ratio (DAR) pada Perusahaan Sub Sektor Property dan Real Estate yang terdaftar di Bursa Efek Indonesia periode 2013-2016 mengalami fluktuasi dan cenderung menurun. Hal ini disebabkan oleh peningkatan total aset yang tidak sebanding dengan peningkatan total utang perusahaan.

3.1.1.2. Profitabilitas pada Perusahaan Sub Sektor Property dan Real Estate Periode 2013-2016

Berikut ini grafik rata-rata profitabilitas Perusahaan Sub Sektor Property dan Real 
Estate yang diukur dengan Return on Assets $(\mathrm{ROA})$ :

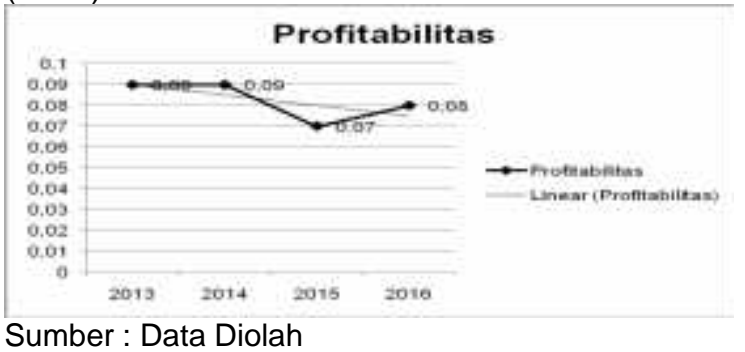

Gambar 3.2

Grafik Rata-rata Profitabilitas pada Perusahaan Sub Sektor Property dan Real Estate Periode 2013-2016

Dari Gambar 3.2, dapat dilihat bahwa profitabilitas yang diukur dengan Return on Assets (ROA) pada Perusahaan Sub Sektor Property dan Real Estate yang terdaftar di Bursa Efek Indonesia periode 2013-2016 mengalami fluktuasi dan cenderung menurun. Hal ini disebabkan oleh laba setelah pajak yang cenderung mengalami penurunan sedangkan total aset perusahaan cenderung mengalami peningkatan.

3.1.1.3. Kebijakan Dividen pada Perusahaan Sub Sektor Property dan Real Estate Periode 2013-2016

Berikut ini grafik rata-rata kebijakan dividen Perusahaan Sub Sektor Property dan Real Estate yang diukur dengan Dividend payout ratio (DPR):

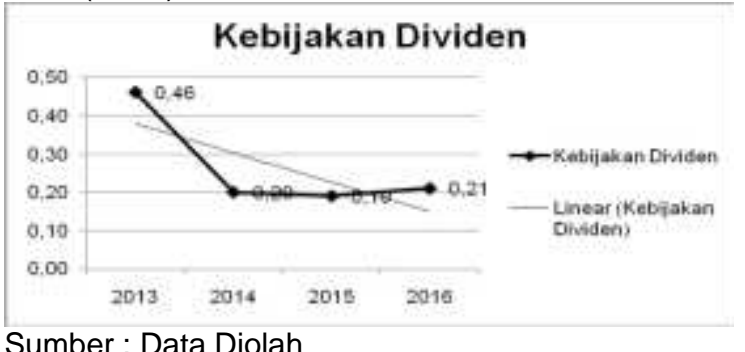

Gambar 3.3

Grafik Rata-rata Kebijakan Dividen pada

Perusahaan Sub Sektor Property dan

Real Estate Periode 2013-2016

Dari Gambar 3.3, dapat dilihat bahwa kebijakan dividen yang diukur dengan Dividend Payout Ratio (DPR) pada Perusahaan Sub Sektor Property dan Real Estate yang terdaftar di Bursa Efek Indonesia periode 2013-2016 mengalami fluktuasi dan cenderung menurun. Hal ini terjadi karena dividen per saham yang dibagikan lebih rendah dikarenakan penurunan profitabilitas perusahaan.

3.1.1.4. Nilai Perusahaan pada Perusahaan Sub Sektor Property dan Real Estate yang terdaftar Periode 2013-2016

Berikut ini grafik rata-rata profitabilitas Perusahaan Sub Sektor Property dan Real Estate yang diukur dengan Price to Book Value (PBV):

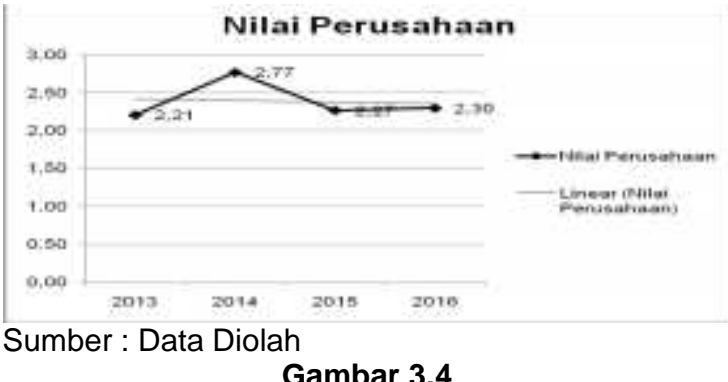

Gambar 3.4

Grafik Rata-rata Nilai Perusahaan pada Perusahaan Sub Sektor Property dan Real Estate Periode 2013-2016

Dari Gambar 3.4, dapat dilihat bahwa nilai perusahaan yang diukur dengan Price to Book Value (PBV) pada Perusahaan Sub Sektor Property dan Real Estate mengalami fluktuasi dan cenderung menurun. Hal ini disebabkan oleh penurunan profitabilitas perusahaan sehingga dividen yang dibagikan juga mengalami penurunan, hal tersebut menyebabkan nilai perusahaan menurun di mata investor.

\subsubsection{Analisis Deskriptif Kuantitatif}

3.1.2.1. Regresi Linear Berganda

1. Regresi Linear Berganda Tanpa Variabel Moderating

Hasil regresi linear berganda tanpa variabel moderating dapat dilihat pada Tabel 2 .

$$
\text { Tabel } 3.1
$$

Hasil Regresi Linear Berganda Tanpa Variabel

\begin{tabular}{|c|c|c|c|}
\hline \multirow[t]{2}{*}{ Model } & \multicolumn{2}{|c|}{$\begin{array}{l}\text { Unstandardized } \\
\text { Coefficients }\end{array}$} & $\begin{array}{l}\text { Standardized } \\
\text { Coefficients }\end{array}$ \\
\hline & B & $\begin{array}{l}\text { Std. } \\
\text { Error }\end{array}$ & Beta \\
\hline (Constant) & $-2,978$ & ,858 & \\
\hline 1 DAR & 7,633 & 1,489 & ,537 \\
\hline $\mathrm{ROA}$ & 23,975 & 4,316 & ,582 \\
\hline
\end{tabular}

Sumber: Hasil Pengolahan Data

Berdasarkan Tabel 3.1, model persamaan regresi yang diperoleh adalah sebagai berikut:

$$
\hat{\mathbf{Y}}=-2,978+7,633 \mathrm{X}_{1}+23,975 \mathrm{X}_{2}
$$

Artinya leverage dan profitabilitas berpengaruh positif terhadap nilai perusahaan pada Perusahaan Sub Sektor Property dan Real Estate yang terdaftar di Bursa Efek Indonesia periode 2013-2016.

2. Regresi Linear Berganda dengan Variabel Moderating

Hasil regresi linear berganda dengan variabel moderating dapat dilihat pada Tabel 3.2:

Tabel 3.2

Hasil Regresi Linear Berganda dengan Variabel Moderating

\begin{tabular}{|l|r|r|r|}
\hline Model & \multicolumn{2}{|c|}{$\begin{array}{c}\text { Unstandardized } \\
\text { Coefficients }\end{array}$} & $\begin{array}{c}\text { Standardized } \\
\text { Coefficients }\end{array}$ \\
\cline { 2 - 5 } & \multicolumn{1}{|c|}{ B } & Std. Error & \multicolumn{1}{c|}{ Beta } \\
\hline (Constant) & $-2,413$ &, 951 & \\
DAR & 6,353 & 1,760 &, 447 \\
ROA & 13,996 & 4,004 &, 340 \\
DPR & 3,345 & 4,004 &, 930 \\
INTERAKSI_1 & $-6,210$ & 8,280 &,- 841 \\
INTERAKSI_2 & 38,027 & 7,171 &, 530 \\
\hline
\end{tabular}


Sumber: Hasil Pengolahan Data

Berdasarkan Tabel 3.2, model persamaan regresi yang diperoleh adalah sebagai berikut: $\hat{Y}=-2,413+6,353 X_{1}+13,996 X_{2}+3,345 X_{3}-$ $6,210 X_{1} X_{3}+38,027 X_{2} X_{3}+$.

Artinya kebijakan dividen memperlemah hubungan leverage dengan nilai perusahaan sementara kebijakan dividen memperkuat hubungan profitabilitas dengan nilai perusahaan pada Perusahaan Sub Sektor Property dan Real Estate yang terdaftar di Bursa Efek Indonesia periode 2013-2016.

\subsubsection{Koefisien Korelasi dan Determinasi}

1. Koefisien Korelasi dan Determinasi Tanpa Variabel Moderating

Hasil analisis koefisien korelasi dan determinasi tanpa variabel moderating dapat dilihat pada Tabel 3.3.

Tabel 3.3

Hasil Analisis Koefisien Korelasi dan

Determinasi Tanpa Variabel Moderating

\begin{tabular}{|l|c|r|r|c|}
\hline Model & $\mathrm{R}$ & $\begin{array}{c}\mathrm{R} \\
\text { Square }\end{array}$ & $\begin{array}{c}\text { Adjusted R } \\
\text { Square }\end{array}$ & $\begin{array}{c}\text { Std. Error of the } \\
\text { Estimate }\end{array}$ \\
\hline 1 &, $659^{\mathrm{a}}$ &, 434 &, 414 & 1,34355 \\
\hline
\end{tabular}

Sumber: Hasil Pengolahan Data

Dari Tabel 3.3, nilai $r$ adalah 0,659 yang berarti terdapat hubungan yang kuat antara leverage (DAR) dan profitabilitas (ROA) dengan nilai perusahaan (PBV). Sementara koefisien determinasi ( $R$ Square) sebesar 0,434 , yang berarti $43,4 \%$ dari nilai perusahaan dijelaskan oleh leverage dan profitabilitas sisanya $56,6 \%$ dapat dijelaskan oleh variabel lain yang tidak diteliti dalam penelitian ini.

2. Koefisien Korelasi dan Determinasi dengan Variabel Moderating

Hasil analisis koefisien korelasi dan determinasi dengan variabel moderating dapat dilihat pada Tabel 3.4.

Tabel 3.4

Hasil Analisis Koefisien Korelasi dan

Determinasi dengan Variabel Moderating

\begin{tabular}{|l|c|r|r|r|}
\hline Model & $\mathrm{R}$ & $\begin{array}{c}\mathrm{R} \\
\text { Square }\end{array}$ & $\begin{array}{c}\text { Adjusted } \mathrm{R} \\
\text { Square }\end{array}$ & $\begin{array}{c}\text { Std. Error of } \\
\text { the Estimate }\end{array}$ \\
\hline 1 &, $844^{\mathrm{a}}$ &, 712 &, 686 &, 98400 \\
\hline
\end{tabular}

Sumber: Hasil Pengolahan Data

Dari Tabel 3.4, nilai $r$ adalah 0,844 yang berarti terdapat hubungan yang sangat kuat antara leverage (DAR) dan profitabilitas (ROA) dengan nilai perusahaan (PBV) yang dimoderasi oleh kebijakan dividen (DPR). Sementara koefisien determinasi ( $R$ Square) sebesar 0,712 , yang berarti $71,2 \%$ dari nilai perusahaan dijelaskan oleh leverage dan profitabilitas sisanya $28,8 \%$ dapat dijelaskan oleh variabel lain yang tidak diteliti dalam penelitian ini.

\subsubsection{Uji Hipotesis}

1. Uji Hipotesis Tanpa Variabel

1) Uji Simultan (Uji F)
Hasil uji F tanpa variabel moderating dapat dilihat pada Tabel 3.5.

Tabel 3.5

Hasil Uji F Tanpa Variabel Moderating

\begin{tabular}{|ll|c|c|}
\hline \multicolumn{2}{|c|}{ Model } & \multicolumn{1}{|c|}{$\mathrm{F}$} & Sig. \\
\hline 1 & Regression & 21,840 &, $000^{\mathrm{b}}$ \\
& $\begin{array}{l}\text { Residual } \\
\text { Total }\end{array}$ & & \\
\hline
\end{tabular}

Sumber: Hasil Pengolahan Data

Dari Tabel 3.5 di atas, diperoleh nilai $F_{\text {hitung }}$ sebesar 21,840 menunjukkan bahwa $F_{\text {hitung }}>$ $F_{\text {tabel }}(21,840>3,16)$ atau dengan signifikansi $0,000<0,05$ maka $\mathrm{H}_{0}$ ditolak, artinya leverage dan profitabilitas berpengaruh signifikan terhadap nilai perusahaan pada Perusahaan Sub Sektor Property dan Real Estate yang terdaftar di Bursa Efek Indonesia.

2) Uji Parsial (Uji t)

Hasil uji t tanpa variabel moderating dapat dilihat pada Tabel 3.6.

Tabel 3.6

Hasil Uji t Tałnpa Variabel Moderating

\begin{tabular}{|c|c|c|c|}
\hline \multirow[t]{2}{*}{ Model } & Standardized & \multirow[t]{2}{*}{$t$} & \multirow[t]{2}{*}{ Sig. } \\
\hline & Beta & & \\
\hline (Constant) & & $-3,471$ & , 001 \\
\hline DAR & ,537 & 5,127 &, 000 \\
\hline ROA &, 582 & 5,555 &, 000 \\
\hline
\end{tabular}

Sumber: Hasil Pengolahan Data

Dari Tabel 3.6, leverage memiliki nilai $t_{\text {hitung }}$ sebesar 5,127 menunjukkan bahwa $t_{\text {hitung }}>t_{\text {tabel }}$ $(5,127>2,00247)$ atau signifikansi $0,000<$ 0,05 maka $\mathrm{H}_{0}$ ditolak, artinya leverage berpengaruh signifikan terhadap nilai perusahaan pada Perusahaan Sub Sektor Property dan Real Estate yang terdaftar di Bursa Efek Indonesia.

Profitabilitas memiliki nilai $t_{\text {hitung }}$ sebesar 5,555 menunjukkan bahwa $t_{\text {hitung }}>t_{\text {tabel }}(5,555>$ $2,00247)$ atau signifikansi $0,000<0,05$ maka $\mathrm{H}_{0}$ ditolak, artinya profitabilitas berpengaruh signifikan terhadap nilai perusahaan pada Perusahaan Sub Sektor Property dan Real Estate, yang terdaftar di Bursa Efek Indonesia.

2. Uji Hipotesis dengan Variabel Moderating

Hasil uji t dengan variabel moderating dapat dilihat pada Tabel 3.7.

Tabel 3.7

Hasil Uji t dengan Variabel Moderating

\begin{tabular}{|l|r|r|r|}
\hline Model & $\begin{array}{r}\text { Standardized } \\
\text { Coefficients }\end{array}$ & \multicolumn{1}{c|}{ T } & Sig. \\
\cline { 2 - 3 } & \multicolumn{1}{|c|}{ Beta } & \\
\hline (Constant) &, 447 & $-2,536$ &, 014 \\
DAR &, 340 & 3,496 &, 001 \\
ROA &, 930 &, 001 \\
ROnn &, 835 &, 407 \\
DPR &,- 841 &,- 750 &, 457 \\
INTERAKSI_1 &, 530 & 5,303 &, 000 \\
\hline
\end{tabular}

mber: Hasil Pengolahan Data

Dari Tabel 3.7, interaksi antara leverage (DAR) dengan kebijakan dividen (DPR) memiliki nilai $t_{\text {hitung }}$ sebesar $-0,750$ 
menunjukkan bahwa $t_{\text {hitung }}<t_{\text {tabel }}(-0,750<$ $2,00488)$ atau dengan taraf signifikan $0,457>$ 0,05 , maka $\mathrm{H}_{0}$ diterima, artinya kebijakan dividen mampu memoderasi namun tidak signifikan hubungan leverage dengan nilai perusahaan pada Perusahaan Sub Sektor Property dan Real Estate yang terdaftar di Bursa Efek Indonesia.

Interaksi antara profitabilitas (ROA) dengan kebijakan dividen (DPR) memiliki nilai $t_{\text {hitung }}$ sebesar $5,303 t_{\text {hitung }}>t_{\text {tabel }}(5,303>2,00488)$ atau dengan taraf signifikan $0,000>0,05$, maka $\mathrm{H}_{0}$ ditolak, artinya kebijakan dividen mampu memoderasi secara signifikan hubungan profitabilitas dengan nilai perusahaan pada Perusahaan Sub Sektor Property dan Real Estate yang terdaftar di Bursa Efek Indonesia.

\subsection{Evaluasi}

3.2.1. Evaluasi Leverage pada Perusahaan Sub Sektor Property dan Real Estate Periode 2013-2016

Hasil analisis menunjukkan bahwa kondisi leverage pada Perusahaan Sub Sektor Property dan Real Estate yang terdaftar di Bursa Efek Indonesia periode 2013-2016 mengalami fluktuasi dan cenderung menurun. Hal ini disebabkan oleh peningkatan total aset yang tidak sebanding dengan peningkatan total utang perusahaan. Oleh karena itu, sebaiknya perusahaan mengelola aset secara efisien dan membatasi peminjaman utang guna mengurangi beban yang harus dibayar perusahaan

\subsubsection{Evaluasi Profitabilitas pada Perusahaan Sub Sektor Property dan Real Estate Periode 2013-2016}

Dari hasil penelitian, menunjukkan kondisi profitabilitas pada Perusahaan Sub Sektor Property dan Real Estate yang terdaftar di Bursa Efek Indonesia periode 2013-2016 yang diukur dengan Return on Assets Ratio (ROA) mengalami fluktuasi dan cenderung menurun. Hal ini disebabkan oleh laba setelah pajak yang cenderung mengalami penurunan sedangkan total aset cenderung mengalami peningkatan. Oleh karena itu, sebaiknya perusahaan meningkatkan laba perusahaan dengan cara mengendalikan manajemen aset sehingga tidak terjadi penumpukan aset terutama pada bagian persediaan dan piutang usaha serta meminimalisir penggunaan beban .

3.2.3. Evaluasi Kebijakan Dividen pada Perusahaan Sub Sektor Property dan Real Estate Periode 2013-2016

Dari hasil penelitian, menunjukkan bahwa kondisi kebijakan dividen pada Perusahaan Sub Sektor Property dan Real Estate yang terdaftar di Bursa Efek Indonesia periode 2013-2016 yang diukur dengan Dividend Payout Ratio (DPR) mengalami fluktuasi dan cenderung menurun. Hal ini disebabkan oleh dividen per saham yang dibagikan lebih rendah dikarenakan penurunan profitabilitas perusahaan. Oleh karena itu, sebaiknya perusahaan meningkatkan profitabilitas perusahaan sehingga dividen yang diberikan perusahaan kepada investor atau pemegang saham akan semakin meningkat.

3.2.4. Evaluasi Nilai Perusahaan pada Perusahaan Sub Sektor Property dan Real Estate Periode 2013-2016

Dari hasil penelitian, menunjukkan kondisi nilai perusahaan pada Perusahaan Sub Sektor Property dan Real Estate yang terdaftar di Bursa Efek Indonesia periode 2013-2016 yang diukur dengan Price to Book Value (PBV) mengalami fluktuasi dan cenderung menurun. Hal ini disebabkan oleh penurunan profitabilitas perusahaan sehingga dividen yang dibagikan juga mengalami penurunan, hal tersebut menyebabkan harga saham menurun sehingga nilai perusahaan menurun di mata investor. Oleh karena itu, sebaiknya perusahaan meningkatkan profitabilitas perusahaan agar dividen yang dibagikan kepada investor juga meningkat sehingga nilai perusahaan meningkat.

3.2.7. Evaluasi Pengaruh Leverage dan Profitabilitas Terhadap Nilai Perusahaan pada Perusahaan Sub Sektor Property dan Real Estate yang terdaftar di Bursa Efek Indonesia

Berdasarkan hasil regresi linear berganda tanpa variabel moderating, dapat diketahui bahwa leverage dan profitabilitas berpengaruh positif terhadap nilai perusahaan. Hal ini dapat dilihat dari persamaan regresi linear berganda tanpa variabel moderating yaitu: $\hat{Y}=-2,978+$ $\mathbf{7}, \mathbf{6 3 3} \mathrm{X}_{1}+\mathbf{2 3}, \mathbf{9 7 5} \mathrm{X}_{2}$. Dari hasil tersebut dapat dijelaskan bahwa nilai koefisien regresi sebesar -2,978 menunjukkan bahwa jika leverage dan profitabilitas bernilai nol, maka nilai perusahaan akan menurun sebesar 2,978.

Leverage sebesar 7,633 berarti bahwa setiap leverage meningkat satu satuan maka nilai perusahaan akan meningkatkan sebesar 7,633 satuan sementara profitabilitas sebesar 23,975 berarti bahwa setiap profitabilitas meningkat satu satuan maka nilai perusahaan akan meningkat sebesar 23,975 satuan, dengan asumsi variabel independen lainnya dianggap tetap atau sama dengan nol.

3.2.8. Evaluasi Pengaruh Leverage dan

Profitabilitas Terhadap Nilai

Perusahaan dengan Kebijakan

Dividen Sebagai Variabel

Moderating pada Perusahaan Sub

Sektor Property dan Real Estate yang terdaftar di Bursa Efek Indonesia

Berdasarkan hasil uji $t$, diperoleh hasil interaksi antara leverage dengan kebijakan dividen yaitu nilai $t_{\text {hitung }}$ sebesar $-0,750$ menunjukkan bahwa $t_{\text {hitung }}<t_{\text {tabel }}(-0,750<$ 
2,00488 ) atau dengan taraf signifikan 0,457 > 0,05 , maka $H_{0}$ diterima, artinya kebijakan dividen mampu memoderasi namun tidak signifikan hubungan leverage dengan nilai perusahaan.

Interaksi antara profitabilitas dengan kebijakan dividen memiliki nilai $t_{\text {hitung }}$ sebesar $5,303 t_{\text {hitung }}>t_{\text {tabel }}(5,303>2,00488)$ atau dengan taraf signifikan $0,000>0,05$, maka $\mathrm{H}_{0}$ ditolak, artinya kebijakan dividen mampu memoderasi secara signifikan hubungan profitabilitas dengan nilai perusahaan.

\section{KESIMPULAN DAN SARAN}

\subsection{Kesimpulan}

1. Nilai leverage pada Perusahaan Sub Sektor Property dan Real Estate periode 20132016 mengalami fluktuasi dan cenderung menurun. Hal ini disebabkan oleh peningkatan total aset yang tidak sebanding dengan peningkatan total utang perusahaan.

2. Nilai profitabilitas pada Perusahaan Sub Sektor Property dan Real Estate periode 2013-2016 mengalami fluktuasi dan cenderung menurun. Hal ini disebabkan oleh laba setelah pajak yang cenderung mengalami penurunan sedangkan total aset cenderung mengalami peningkatan.

3. Nilai kebijakan dividen pada Perusahaan Sub Sektor Property dan Real Estate periode 2013-2016 mengalami fluktuasi dan cenderung menurun. Hal ini disebabkan oleh dividen per saham yang dibagikan lebih rendah dikarenakan penurunan profitabilitas perusahaan.

4. Nilai perusahaan pada Perusahaan Sub Sektor Property dan Real Estate periode 2013-2016 mengalami fluktuasi dan cenderung menurun. Hal ini disebabkan oleh penurunan profitabilitas perusahaan sehingga dividen yang dibagikan juga mengalami penurunan, hal tersebut menyebabkan harga saham menurun sehingga nilai perusahaan menurun di mata investor.

5. Hasil regresi linear berganda diperoleh :

1) Hasil regresi tanpa moderating diketahui bahwa leverage dan profitabilitas berpengaruh positif terhadap nilai perusahaan pada Perusahaan Sub Sektor Property dan Real Estate yang terdaftar di Bursa Efek Indonesia periode 20132016.

2) Hasil regresi dengan moderating diketahui bahwa kebijakan dividen memperlemah hubungan leverage dengan nilai perusahaan sementara kebijakan dividen memperkuat hubungan profitabilitas dengan nilai perusahaan pada Perusahaan Sub Sektor Property dan Real Estate yang terdaftar di Bursa Efek Indonesia periode 2013-2016.

6. Hasil uji koefisien korelasi dan determinasi diperoleh:

1) Hasil koefisien korelasi tanpa variabel moderating diketahui bahwa terdapat hubungan yang kuat antara leverage dan profitabilitas dengan nilai perusahaan. Sementara untuk hasil determinasi diketahui bahwa nilai perusahaan dapat dijelaskan oleh leverage dan profitabilitas pada Perusahaan Sub Sektor Property dan Real Estate yang terdaftar di Bursa Efek Indonesia periode 20132016.

2) Hasil koefisien korelasi dengan variabel moderating diketahui bahwa terdapat korelasi atau hubungan yang sangat kuat antara leverage dan profitabilitas dengan nilai perusahaan yang dimoderasi oleh kebijakan dividen. Sementara untuk hasil determinasi diketahui bahwa nilai perusahaan dapat dijelaskan oleh leverage dan profitabilitas dengan kebijakan dividen sebagai variabel moderating pada Perusahaan Sub Sektor Property dan Real Estate yang terdaftar di Bursa Efek Indonesia periode 20132016.

7. Hasil hipotesis dengan uji $F$ tanpa moderating bahwa secara simultan dapat disimpulkan leverage dan profitabilitas berpengaruh signifikan terhadap nilai perusahaan pada Perusahaan Sub Sektor Property dan Real Estate yang terdaftar di Bursa Efek Indonesia.

8. Hasil hipotesis dengan uji t bahwa secara parsial diperoleh:

1) Hasil hipotesis tanpa moderating dapat disimpulkan bahwa leverage dan profitabilias berpengaruh signifikan terhadap nilai perusahaan pada Perusahaan Sub Sektor Property dan Real Estate yang terdaftar di Bursa Efek Indonesia.

2) Hasil hipotesis dengan moderating dapat disimpulkan bahwa kebijakan dividen mampu memoderasi namun tidak signifikan hubungan leverage dengan nilai perusahaan sementara kebijakan dividen mampu memoderasi secara signifikan hubungan profitabilitas dengan nilai perusahaan di Perusahaan Sub Sektor Property dan Real Estate, yang terdaftar di Bursa Efek Indonesia.

4.2. Saran

1. Sebaiknya perusahaan mengelola aset secara efisien dan membatasi peminjaman utang guna mengurangi beban yang harus dibayar perusahaan. 
2. Sebaiknya perusahaan meningkatkan laba perusahaan dengan cara mengendalikan manajemen aset sehingga tidak terjadi penumpukan aset terutama pada bagian persediaan dan piutang usaha serta meminimalisir penggunaan beban.

3. Sebaiknya perusahaan meningkatkan profitabilitas perusahaan sehingga dividen yang diberikan perusahaan kepada investor atau pemegang saham akan semakin meningkat.

4. Sebaiknya perusahaan meningkatkan profitabilitas perusahaan agar dividen yang dibagikan kepada investor juga meningkat sehingga nilai perusahaan meningkat.

\section{DAFTAR PUSTAKA}

Astuti, Dewi. 2004. Manajemen Keuangan Perusahaan. Jakarta: Ghalia Indonesia.

Brigham Eugene F. dan Joel F. Houston. 2011. Dasar-dasar Manajemen Keuangan 1, Buku 2, Edisi 11. Jakarta: Salemba Empat.

2010. Dasar-dasar Manajemen Keuangan 1, Buku 1, Edisi 11. Jakarta: Salemba Empat.

Halim, Abdul. 2007. Manajemen Keuangan Bisnis. Jakarta: Ghalia Indonesia.

Hery. 2009. Akuntansi Keuangan Menengah

1, Cetakan pertama. Jakarta: PT Bumi Aksara.
Horne, James C.Van dan John M.Wachowiccz, Jr. 2012. Prinsip-Prinsip Manajemen Keuangan. Buku 1, Edisi XIII. Jakarta: Salemba Empat.

Kasmir. 2010. Pengantar Manajemen Perusahaan, Edisi Pertama, Cetakan Pertama. Jakarta : Kencana.

Lestari, Erna Yuliana. 2017. Pengaruh Likuiditas, Leverage, Dan Profitabilitas Terhadap Nilai Perusahaan Dengan Kebijakan Dividen Sebagai Variabel Moderating. Yogyakarta: Muhammadiyah.

Riyanto, Bambang. 2009. Dasar-Dasar Pembelanjaan Perusahaan. Yogyakarta: BPFE.

Rudianto. 2009. Pengantar Akuntansi. Jakarta: Erlangga.

Subramanyam, K.R. dan John J. Wild. 2010. Analisis Laporan Keuangan. Jakarta: Salemba Empat.

Sudana, I Made. 2011. Manajemen Keuangan Perusahaan Teori Dan Praktik. Jakarta: Erlangga.

Syahyunan. 2015. Manajemen Keuangan, Edisi Kedua. Medan: USU Press.

Weygandt, Donald dan Paul D. Kimmel. 2008. Pengantar Akuntansi. Jakarta: Salemba Empat. 